\title{
Optimization of physical factors affecting the production of thermo-stable organic solvent-tolerant protease from a newly isolated halo tolerant Bacillus subtilis strain Rand
}

\author{
Randa A Abusham ${ }^{\dagger 1}$, Raja Noor Zaliha RA Rahman* ${ }^{* 1}$, Abu Bakar Salleh ${ }^{\dagger 1}$ \\ and Mahiran Basri ${ }^{\dagger 2}$
}

Address: ${ }^{1}$ Enzyme and Microbial Technology Research Group, Faculty of Biotechnology and Biomolecular Sciences, Universiti Putra Malaysia, 43400 UPM Serdang, Selangor, Malaysia and 'Enzyme and Microbial Technology Research Group, Faculty of Science, Universiti Putra Malaysia, 43400 UPM Serdang, Selangor, Malaysia

Email: Randa A Abusham - noia25@hotmail.com; Raja Noor Zaliha RA Rahman* - rnzaliha@biotech.upm.edu.my; Abu Bakar Salleh - abubakar@biotech.upm.edu.my; Mahiran Basri - mahiran@science.upm.edu.my

* Corresponding author †Equal contributors

Published: 9 April 2009

Microbial Cell Factories 2009, 8:20 doi:10.1186/1475-2859-8-20
Received: 26 December 2008

Accepted: 9 April 2009

This article is available from: http://www.microbialcellfactories.com/content/8/I/20

(c) 2009 Abusham et al; licensee BioMed Central Ltd.

This is an Open Access article distributed under the terms of the Creative Commons Attribution License (http://creativecommons.org/licenses/by/2.0), which permits unrestricted use, distribution, and reproduction in any medium, provided the original work is properly cited.

\begin{abstract}
Background: Many researchers have reported on the optimization of protease production; nevertheless, only a few have reported on the optimization of the production of organic solventtolerant proteases. Ironically, none has reported on thermostable organic solvent-tolerant protease to date. The aim of this study was to isolate the thermostable organic solvent-tolerant protease and identify the culture conditions which support its production. The bacteria of genus Bacillus are active producers of extra-cellular proteases, and the thermostability of enzyme production by Bacillus species has been well-studied by a number of researchers. In the present study, the Bacillus subtilis strain Rand was isolated from the contaminated soil found in Port Dickson, Malaysia.

Results: A thermostable organic solvent-tolerant protease producer had been identified as Bacillus subtilis strain Rand, based on the I6S rRNA analysis conducted, as well as the morphological characteristics and biochemical properties. The production of the thermostable organic solventtolerant protease was optimized by varying various physical culture conditions. Inoculation with $5.0 \%(\mathrm{v} / \mathrm{v})$ of $\left(\mathrm{AB}_{600}=0.5\right)$ inoculum size, in a culture medium $(\mathrm{pH} 7.0)$ and incubated for $24 \mathrm{~h}$ at $37^{\circ} \mathrm{C}$ with $200 \mathrm{rpm}$ shaking, was the best culture condition which resulted in the maximum growth and production of protease $(444.7 \mathrm{U} / \mathrm{ml} ; 4042.4 \mathrm{U} / \mathrm{mg})$. The Rand protease was not only stable in the presence of organic solvents, but it also exhibited a higher activity than in the absence of organic solvent, except for pyridine which inhibited the protease activity. The enzyme retained 100, 99 and $80 \%$ of its initial activity, after the heat treatment for $30 \mathrm{~min}$ at 50,55 , and $60^{\circ} \mathrm{C}$, respectively.

Conclusion: Strain Rand has been found to be able to secrete extra-cellular thermostable organic solvent-tolerant protease into the culture medium. The protease exhibited a remarkable stability towards temperature and organic solvent. This unique property makes it attractive and useful to be used in industrial applications.
\end{abstract}




\section{Background}

Currently, enzymes have attracted the world attention due to their wide range of industrial applications in many fields, including organic synthesis, clinical analysis, pharmaceuticals, detergents, food production and fermentation. Enzymes are gradually replacing the use of harsh chemicals in various industrial processes [1]. Proteases are one of the most important groups of industrial enzymes and they account for nearly $60 \%$ of the total enzyme sale [2-4].

In industrial applications, with thermopiles and thermostable enzymes, the isolation of enzymes is dominating over micro-organisms [5]. Bacterial proteases, especially from Bacillus sp., are the most widely exploited industrial enzymes and among the bacteria, Bacillus sp., are producers of extra-cellular proteases [6].

The industrial use of proteases, in detergents and in leather processing, requires that the enzymes be stable at higher temperatures. Thermostable proteases are advantageous in some applications because of the higher processing temperatures which can be employed, resulting in much faster reaction rates, increasing the solubility of non-gaseous reactants and products, and reducing the incidence of microbial contamination by mesophilic organisms [7].

Thermophilic enzymes are potentially applicable in a wide range of industrial processes, particularly and mainly due to their denaturant tolerance and extraordinary operational stability at high temperatures. Such enzymes are used in chemical, food, pharmaceutical, paper, textile and other industries $[5,8,9]$.

Enzymatic conversions in non-aqueous media have been shown to possess many potential industrial applications. The areas of application vary widely from food additives, flavours and fragrances to pharmaceuticals, pesticides and specialty polymers [10]. Enzymes, which are stable and active in non-aqueous media, are in large demand for their increasing application in organic synthesis [11]. The use of proteases in peptide synthesis is limited by the specificity and the instability of the enzymes in the presence of organic solvents, since reactions occurred in organic media. However, little attention has been given to the study of organic solvent-stable protease [12].

Each organism or strain has its own special conditions for the maximum enzyme production [13]. The general rules for the optimization of microbial protease production are affected by various physical factors which include $\mathrm{pH}$, cultivation temperature, shaking condition and aeration. These factors are important to promote, stimulate, enhance and optimize the production of proteases [14].
However, cultivation conditions are essential in a successful production of an enzyme, while optimization parameters, such as $\mathrm{pH}$ and temperature, are important in developing this cultivation process [15].

In this study, the effects of physical factors on the production of a thermostable organic solvent-tolerant protease, from Bacillus subtilis strain Rand, were identified and investigated.

\section{Results and discussion}

\section{Screening and isolation of bacteria}

Contamination and hot surrounding area may provide a good environment for the growth of micro-organisms producing thermostable, organic solvent-tolerant proteases. Several samples were obtained from a car service workshop located in Port Dickson, and hot spring water from Batang Kali and Selayang, Malaysia. The temperatures were between 45 to $90^{\circ} \mathrm{C}$ when the sample was collected. From a comprehensive screening on the Skim Milk Agar (SMA) plate, ten isolates (L1, L2, BK, BK1, BK2, PD, PD1, PD2, PD and Rand) showed positive results by forming zone of lyses around the colonies on the SMA. All these isolates were found to be able to produce protease (data not shown). Among the ten isolates, Rand was detected to have the highest protease activity $(34.9 \mathrm{U} / \mathrm{ml})$, and was selected for further study.

\section{Identification of isolate Rand} I6S rDNA analysis

The primers are highly conserved among prokaryotes and found to amplify the whole region of the rRNA gene, which is $1500 \mathrm{bp}$. The PCR product sequencing was done by the First BASE Laboratories Sdn Bhd (Shah Alam, Selangor, Malaysia). The DNA homology search on the GenBank database http://www.ncbi.nih.gov was performed. A phylogenetic tree was constructed based on the comparison of the $16 \mathrm{~S}$ rDNA sequence of this isolate and other strain of Bacillus. All the sequences were aligned with CLUSTALW from Biology Workbench database at http://workbench.sdsc.edu[16]. 16S rDNA sequences of other Bacillus were obtained from the GenBank database http://www.ncbi.nih.gov. The results gathered from the 16S rDNA analyses show that Bacillus subtilis strain Rand is very close to Brevibacterium halotolerans, Bacillus malacintesis strain LMG 22477, Bacillus malacitensis strain CECT 5687 and Bacillus axarquiensis strain LMG 22476 (Figure 1 ). The partial sequencing of the $16 \mathrm{~S}$ rDNA shows a 99.6\% similarity to different strains of Bacillus subtilis. In addition, the analysis of the cellular fatty acids also shows a good correspondence to the profile of the Bacillus subtilis group.

Strain Rand is an aerobic, rod-shaped, with $0.7-0.8 \mu \mathrm{m}$ in width and 2.5-3.0 $\mu \mathrm{m}$ in length gram positive bacteria. 


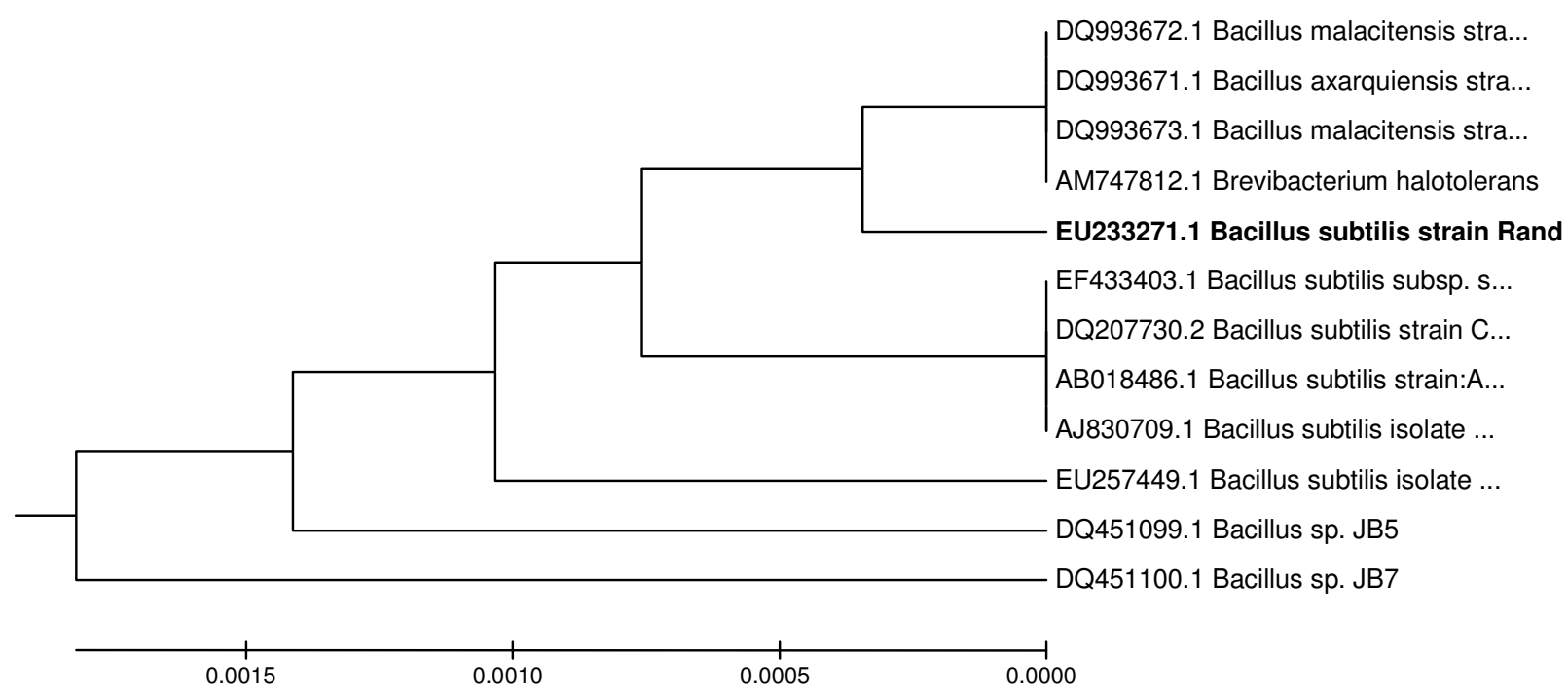

\begin{abstract}
Figure I
Phylogenetic position of strain Rand with other bacteria. The members of bacteria used include Bacillus malacitensis CECT 5687; Bacillus axarquiensis LMG 22476; Bacillus malacintesis LMG 22477; Brevibacterium halotolerans;Bacillus subtilis subsp. spizizenii BCRC 10447;Bacillus subtilis CCM 1999; Bacillus subtilis AU30; Bacillus subtilis isolate KCM-RG5; Bacillus subtilis isolate CIO-I. Phylogenetic tree was inferred by using the neighbour-joining methods. The software package MEGA 4 was used for analysis.
\end{abstract}

The biochemical, morphological and physiological properties of strain Rand are listed in Table 1.

According to the $16 \mathrm{~S}$ rDNA analysis, the biochemical results and morphological properties of the bacterium were identified as Bacillus subtilis strain Rand.

\section{Organic solvent-stability of crude enzyme}

Enzymes are usually inactivated or denaturated in the presence of organic solvents [12]. The effects of different organic solvents on protease stability were studied. The relative activity, which remained after 30 min of incubation in $25 \%(\mathrm{v} / \mathrm{v})$ of organic solvent, is shown in Table 2. The activity of the enzyme, without any solvent (control), was taken as $100 \%$. Rand protease showed a remarkable stability in the presence of all of the solvents, except pyridine $(\log P 0.71)$ as shown in Table 2. The remaining activity of the Rand protease was found to be 104, 197, $130,134,146,209,151,152$ and $151 \%$ in the presence of butanol, benzene, toluene, $p$-xylene, $n$-hexane, $n$-decane, $n$-dodacane, $n$-tetradecane and $n$-hexadecane, respectively (data not shown). This level of stability, towards hydrophobic and hydrophilic solvents, is unique. The remaining activities of alkaliphilic protease, from Bacillus subtilis TKU07, were $65 \%$ and $90 \%$ in the presence of only $20 \%$ (v/v) of butanol and toluene [17]. Gupta and Khare reported that crude $P$. aeruginosa PseA protease showed a remarkable stability in the presence of most solvents, having the logarithm of the partition coefficient $(\log P)$ above 2.0, but was less stable in the presence of hydrophilic solvents [11]. The stability of the Pseudomonas aeruginosa protease, in the presence of organic solvents (of which the values of the $\log P$ were equal to or more than 3.2 ), was almost the same as the one found in the absence of organic solvents [18]. Purified protease, from Pseudomonas aeruginosa PseA strain, was found to be stable in the presence of a range of organic solvents, but was detected to be less stable in benzene and isooctane [19]. In another study, the protease from Pseudomonas aeruginosa stain K was activated when compared to the control, in the presence of $25 \%$ organic solvents, with the $\log P$ values exceeding 4.0; however, in the presence of $25 \%$ organic solvents with the $\log P$ values below 4.0, the stability of the protease was lesser after $30 \mathrm{~min}$ of incubation [20]. Slightly over $20 \%$ of the activity remained [21] in the crude protease derived from Pseudomonas aeruginosa sanai, in the presence of butanol, chloroform, and hexane. However, the results in this study showed that the protease, from the Rand strain, was not only stable in the presence of various organic solvents (with the $\log P$ val- 
Table I: Morphological and biochemical characteristics of Bacillus subtilis strain Rand

\begin{tabular}{|c|c|}
\hline Characteristics & Isolate Rand results \\
\hline Rods & + \\
\hline Width $\mu \mathrm{m}$ & $0.7-0.8$ \\
\hline Length $\mu \mathrm{m}$ & $2.5-3.0$ \\
\hline Aminopeptidase test & - \\
\hline $\mathrm{KOH}$ test & - \\
\hline Oxidase & + \\
\hline Catalase & + \\
\hline Gram stain & + \\
\hline Spores & + \\
\hline Sporangium swollen & - \\
\hline Anaerobic growth & - \\
\hline VP reaction & + \\
\hline $\mathrm{pH}$ in VP broth & 5.5 \\
\hline Growth positive at & $50^{\circ} \mathrm{C}$ \\
\hline Growth negative at & $55^{\circ} \mathrm{C}$ \\
\hline Growth in medium $\mathrm{pH} 5.7$ & + \\
\hline $\mathrm{NaCl} 2 \%$ & + \\
\hline $5 \%$ & + \\
\hline $7 \%$ & + \\
\hline $10 \%$ & + \\
\hline \multicolumn{2}{|l|}{ Acid form } \\
\hline D-glucose & + \\
\hline L-arabinose & + \\
\hline D-xylose & + \\
\hline D-mannitol & + \\
\hline D-frucrose & + \\
\hline Use of citrate & + \\
\hline propionate & - \\
\hline $\mathrm{NO}_{2}$ from $\mathrm{NO}_{3}$ & + \\
\hline Indol reaction & - \\
\hline Phenylalanine deaminase & - \\
\hline Arginine dihydrolase & - \\
\hline Hydrolysis of Starch & + \\
\hline Gelatin & + \\
\hline Casein & + \\
\hline Tween 80 & + \\
\hline
\end{tabular}

ues equalled to or more than 2.0), but also in the presence of some organic solvents with the Log P values below 2.0. These results indicated that this protease might be a novel solvent-stable protease.

\section{Thermostability of crude enzyme}

Another remarkable feature of the Rand protease is its stability in high temperatures. To study the stability of enzyme at different temperatures, crude enzyme was pre-
Table 2: Effect of organic solvents on Rand protease stability

\begin{tabular}{cclc}
\hline Organic solvents & Log $P^{*}$ & \multicolumn{2}{c}{ Protease activity $(\mathrm{U} / \mathrm{ml})$} \\
& & 0 min & $30 \mathrm{~min}$ \\
\hline Pyridine & 0.71 & 22.66 & 0.0 \\
butanol & 0.80 & 23 & 38.3 \\
benzene & 2.0 & 61.9 & 72.7 \\
toluene & 2.5 & 45.7 & 47.9 \\
p-xylene & 3.1 & 54.4 & 49.6 \\
n-hexane & 3.5 & 47.22 & 53.9 \\
n-decane & 5.6 & 53.4 & 77.4 \\
n-dodacane & 6.0 & 65 & 55.7 \\
n-tetradecane & 7.6 & 44.7 & 56.4 \\
n-hexadecane & 8.8 & 61.9 & 56 \\
None & & 37 & 37 \\
\hline
\end{tabular}

* Adopted from Laane et al. [22]

Note: $25 \%(\mathrm{v} / \mathrm{v})$ of organic solvents were added to the cell-free supernatant and incubated at $50^{\circ} \mathrm{C}$ with shaking $150 \mathrm{rpm}$ for $30 \mathrm{~min}$.

incubated at different temperatures ranging from 37 to $70^{\circ} \mathrm{C}$ for $30 \mathrm{~min}$, rapidly cooled, and the protease activities were measured by the standard assay procedure. The protease appeared to be stable and was found to be able to retain its full activity after $30 \mathrm{~min}$ of incubation in the temperature ranging from 37 to $55^{\circ} \mathrm{C}$ (Figure 2). The crude enzyme retained $80 \%$ activity $(0.086 \mathrm{mg} / \mathrm{ml})$, even after the heat treatment at $60^{\circ} \mathrm{C}$ for $30 \mathrm{~min}$. A reduction in the enzyme activity was observed at the temperature values above $60^{\circ} \mathrm{C}$.

The Rand protease is more thermostable than other organic solvent tolerant proteases. Ghorbel et al. isolated a protease from Bacillus cereus BG1 which retained 89.5 of its original activity, after 15 -min incubation at $55^{\circ} \mathrm{C}$, in the presence of $2 \mathrm{mM} \mathrm{Ca}^{2+}$; meanwhile, no activity was detected in the absence of $\mathrm{Ca}^{2+}[12]$. An organic solvent-

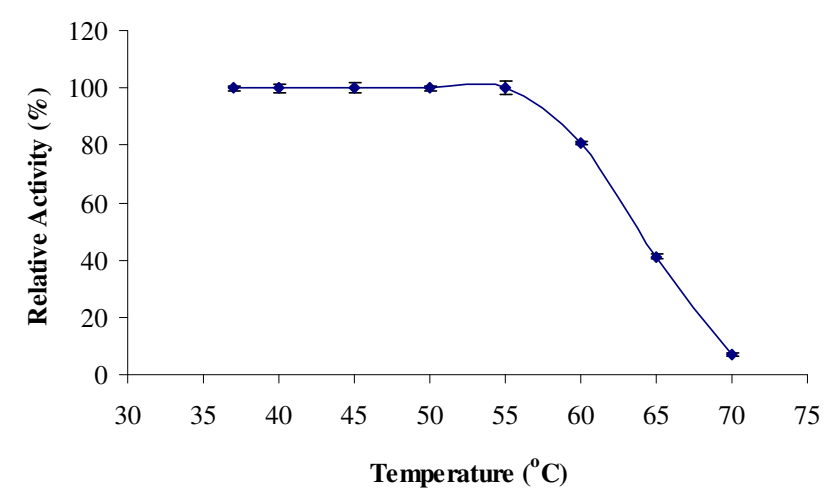

Figure 2

Effect of Temperature on Protease Stability. The crude enzyme was incubated at different temperatures (37$70^{\circ} \mathrm{C}$ ) for $30 \mathrm{~min}$ with shaking $150 \mathrm{rpm}$. Protease activity at $37^{\circ} \mathrm{C}$ was considered as $100 \%$. 
stable protease from Pseudomonas aeruginosa PST-01 was reported to be stable at the temperature below $50^{\circ} \mathrm{C}$ [23]. A solvent stable protease, from Pseudomonas aeruginosa PseA retained $80 \%$ of its initial activity after heating, for $30 \mathrm{~min}$ at $55^{\circ} \mathrm{C}[11]$. In particular, TKU004 metalloprotease had $10 \%$ of its activity retained at $60^{\circ} \mathrm{C}$, but was completely inactivated at $70^{\circ} \mathrm{C}$ [24]. The Rand protease displayed a greater stability at higher temperatures, and thus was suitable to be used in industrial and biotechnological applications.

The effects of temperature on the production of protease Temperature is a critical parameter which needs to be controlled and this is usually varied from organism to another [13]. The optimum temperature for the production of protease and bacterial growth was investigated from $30^{\circ} \mathrm{C}$ to $65^{\circ} \mathrm{C}$. In shaken cultures, $37^{\circ} \mathrm{C}$ was found to the optimum temperature for both protease production and bacterial growth (Figure 3). The incubation at 30, 40, 45 and $50^{\circ} \mathrm{C}$ was found to decrease the production of protease, and no protease activity was detected at 55,60 and $65^{\circ} \mathrm{C}$. The optimum temperature for crude protease, produced from B. subtilis strain 38 , was $47^{\circ} \mathrm{C}$ [25]. The optimum temperature for the protease produced by Bacillus sp. MIG was found to be $30^{\circ} \mathrm{C}$ [26]. Meanwhile, the optimum temperature for the production of protease by Bacillus sp SMIA-2 was $60^{\circ} \mathrm{C}$ [7]. The optimum temperature for the protease produced by Bacillus licheniformis was $50^{\circ} \mathrm{C}$ [27]. The studies by Frankena et al. [28] showed that there was a link between enzyme synthesis and energy metabolism in bacteria, and this was controlled by the temperature and oxygen uptake. As for the extra-cellular enzymes, temperature was found to influence their secretion, possibly by changing the physical properties of the cell membrane

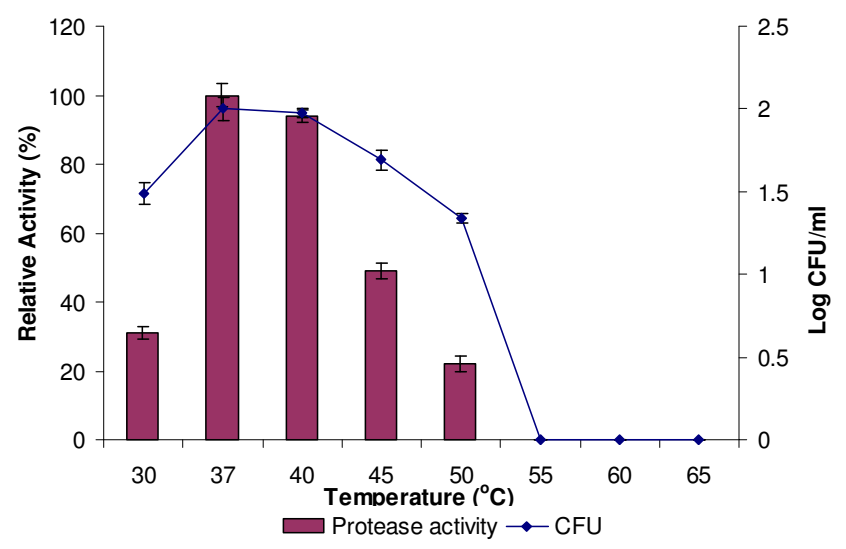

\section{Figure 3}

Effect of temperature on protease production. Culture media were incubated at 30,37, 40, 45, 50, 55, 60 and $65^{\circ} \mathrm{C}$ with shaking at $150 \mathrm{rpm}$ for $24 \mathrm{~h}$. Protease activity at $37^{\circ} \mathrm{C}$ was considered as $100 \%$.
[14]. On the other hand, a lower growth of Rand strain at high temperatures could be due to the lack of dissolved oxygen in the medium, which resulted to a low protease activity. It is a well-known fact that protein conformation changes or degraded at higher temperatures, and hence, causes a decrease in the protease activity [29].

\section{The effects of $\mathrm{pH}$ on the production of protease}

The $\mathrm{pH}$ of the medium started to decrease after 4 h to 4.5 after $8 \mathrm{~h}$ of growth (Figure 4 ). The increased acidity was due to the production of acids during the bacterial growth. After that, the $\mathrm{pH}$ was slightly increased to 5.2 at $12 \mathrm{~h}$, and to 6.4 at $16 \mathrm{~h}$. It turned neutral at $20 \mathrm{~h}$ and remained constant up to $48 \mathrm{~h}$. The rise in the $\mathrm{pH}$ after $8 \mathrm{~h}$ of incubation could be due to utilization of organic acids or the production of alkaline compounds.

Extra-cellular protease was detected over a broad $\mathrm{pH}$ range ( $\mathrm{pH} 4.0$ to 9.0), with the optimum production of protease and bacterial growth exhibited at pH 7.0 (Figure 5). The bacterial growth and production of protease in an acidic medium at $\mathrm{pH} 6.0$ were higher as compared to that in alkaline at $\mathrm{pH}$ 8.0. However, at an extreme acidity of $\mathrm{pH}$ 4.0 , the production of protease was found to be greatly reduced. The optimum $\mathrm{pH}$ for the production of protease determined in this study is in agreement with the optimum $\mathrm{pH}$ for the protease from Bacillus sp. MIG [26]. The crude protease enzyme, produced from $B$. subtilis strain 38 , had the optimal pH at 6.5 [25]. Malathu et al. reported an extra-cellular protease from a novel bacterial isolate showing the maximum activity at $\mathrm{pH} 7.5$ [1]. Meanwhile, Nascimento and Martins reported an optimum pH of 8.0 for a protease derived from therophilic Bacillus sp strains SMIA-2 [7].

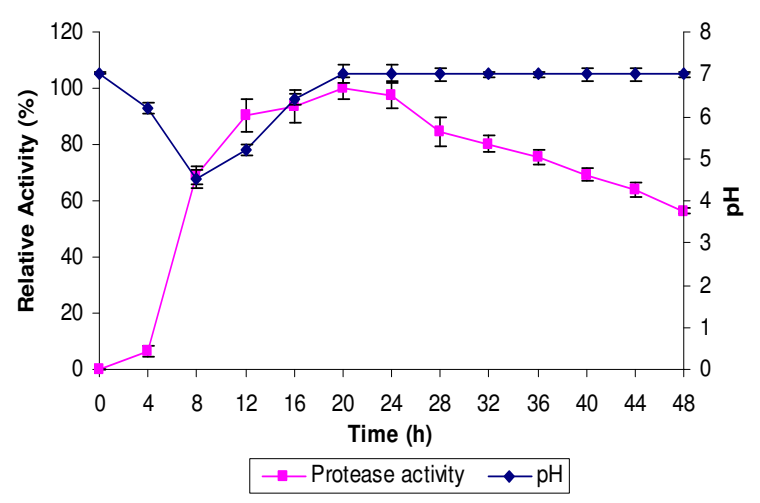

Figure 4

Time course of protease activity and $\mathrm{pH}$ of the medium. Culture media were incubated at $37^{\circ} \mathrm{C}$ with shaking at $150 \mathrm{rpm}$ for $48 \mathrm{~h}$. Samples were taken at $4 \mathrm{~h}$ intervals to determine the protease activity and the $\mathrm{pH}$ level. 


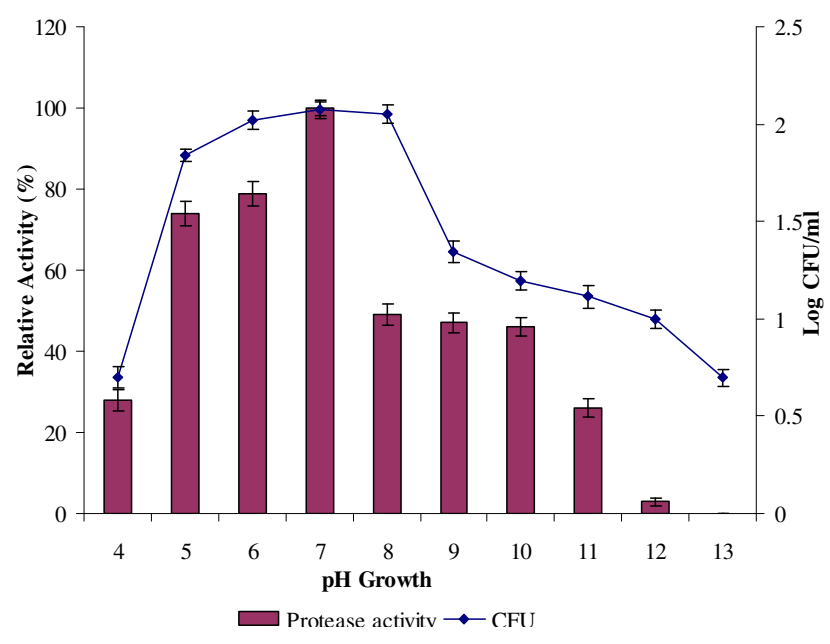

Figure 5

Effect of $\mathrm{pH}$ on protease production. Bacterial cultures were adjusted to $\mathrm{pH} 4,5.0,6.0,7.0,8.0,9.0,10.0,11.0,12.0$, 13.0 and incubated at $37^{\circ} \mathrm{C}$ with $150 \mathrm{rpm}$ for $24 \mathrm{~h}$. Protease activity at $\mathrm{pH} 7$ was considered as $100 \%$.

Moon and Parulekar [30] reported that the $\mathrm{pH}$ of culture has been shown to strongly affect many enzymatic processes and transportation of various components across the cell membrane.

The effect of agitation rate on the production of protease Micro-organisms vary in their oxygen requirements. In particular, oxygen acts as a terminal electron acceptor for oxidative reactions to provide energy for cellular activities. The variation in the agitation speed has been found to influence the extent of mixing in the shake flasks or the bioreactor, and also affect the nutrient availability [7].

The effects of agitation rate on the production of protease and bacterial growth were investigated. Figure 6 shows that the highest protease production and bacteria growth were obtained when agitated at $200 \mathrm{rpm}$. At this speed, the aeration of the culture medium was increased, and this further led to a sufficient supply of dissolved oxygen in the media [13]. Although the production of protease was found to decrease when shaken at $250 \mathrm{rpm}$, the static condition almost inhibited its production.

As a conclusion, higher agitation rates could increase the oxygen pressure of the system but did not bring about the increase in production, probably because at a high agitation rate, the structure of enzyme would be altered [31]. However, lowering the aeration rate could cause a drastic reduction in the protease yields [24]. This indicates that a

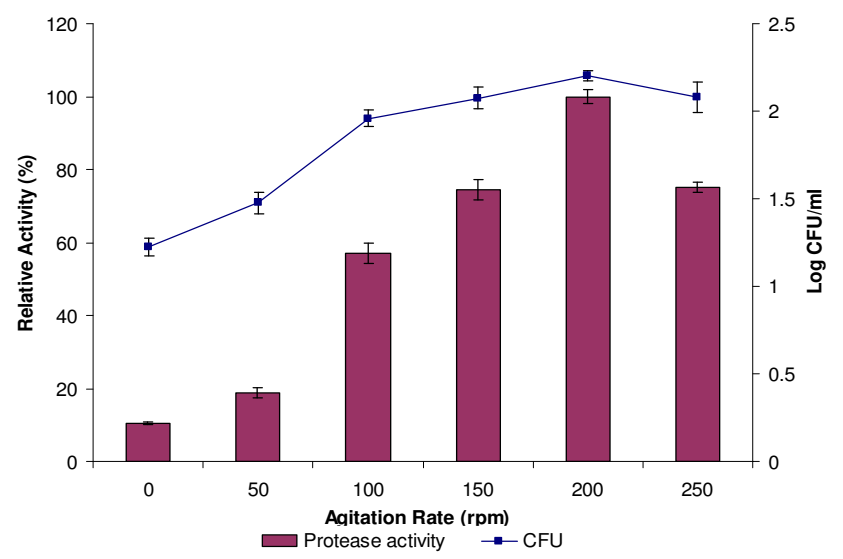

Figure 6

Effect of agitation rate on protease production. Culture media were incubated at $37^{\circ} \mathrm{C}$ with different shaking rates $(0,50,100,150,200$ and $250 \mathrm{rpm})$ for $24 \mathrm{~h}$. Protease activity at $200 \mathrm{rpm}$ was considered as $100 \%$.

reduction in oxygen supply is an important limiting factor for growth as well as protease synthesis [7].

The effects of inoculum size on the production of protease The finite volume of a culture medium means that it can only contain limited nutrients for the micro-organism. Furthermore, the consumption of the nutrients is largely dependent on the population of bacteria. To ensure a high production of enzyme in the limited volume of medium, the bacterial inoculum size should therefore be controlled.

Inoculating several production media, with various inoculum sizes (from 1\% to $11 \%$ ) of the isolate Rand, could affect the production of protease and bacterial growth. The maximum production of protease and bacterial growth were achieved with an inoculum size of $5 \%(\mathrm{v} / \mathrm{v})$ (Figure 7). Similar result was also reported by Mabrouk et al. [32] who found the maximum production of protease by Bacillus licheniformis ATCC21415 with an inoculum size of $5 \%(\mathrm{v} / \mathrm{v})$. A higher inoculum of $11 \%(\mathrm{v} / \mathrm{v})$ was found to reduce the production of protease more than if the lower inoculum size of $1 \%(\mathrm{v} / \mathrm{v})$ was used. Therefore, high inoculum sizes do not necessarily give higher protease yield. The increase in the production of protease using small inoculum sizes was suggested to be due to the higher surface area to volume ratio, which resulted in the increased production of protease [14]. In addition, an improved distribution of dissolve oxygen and more effective uptake of nutrient also contributed to a higher protease production. If the inoculum sizes are too small, insufficient number of bacteria would then lead to a reduced amount of secreted protease [33]. 


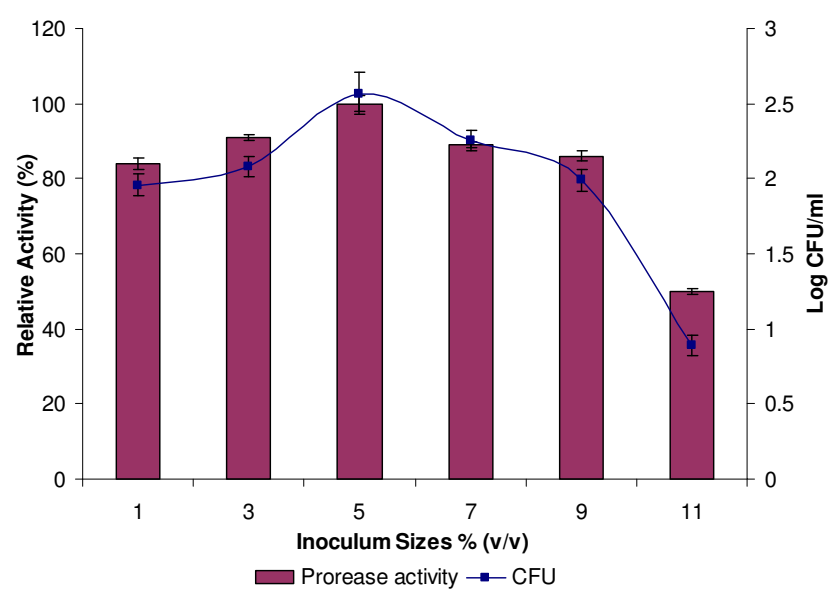

\section{Figure 7}

Effect of inoculum size on protease production. Culture media were incubated with I.0, 3.0, 5.0, 7.0, 9.0 and I I. $0 \%(\mathrm{v} / \mathrm{v})$ of inoculum and incubated at $37^{\circ} \mathrm{C}$ with shaking at $200 \mathrm{rpm}$ for $24 \mathrm{~h}$. Protease activity at with an inoculum size of $5 \%(\mathrm{v} / \mathrm{v})$ was considered as $100 \%$.

However, higher inoculum sizes could lead to or cause a lack of oxygen and depletion of nutrient in the culture media. Different optimum inoculum sizes have been reported by other researchers for different bacteria: $1.0 \%$ (v/v) for Aspergillus flavus [34] and 4.0\% (v/v) for Pseudomonas aeruginosa strain K [14].

Under optimized conditions (growth temperature of $37^{\circ} \mathrm{C}$; bacterial inoculum size at $\mathrm{AB}_{600}=0.5,5 \%(\mathrm{v} / \mathrm{v})$; initial pH of 7.0; 24 h of incubated time; agitation rate of 200 $\mathrm{rpm}$ ), the highest protease activity of $444.7 \mathrm{U} / \mathrm{ml}$ (4042.4 $\mathrm{U} / \mathrm{mg}$ ) was obtained.

\section{Conclusion}

The aim of this study was to optimize the physical factors affecting the productions of thermostable and organic solvent-tolerant protease. For this purpose, the organic solvent-tolerant and thermostabe protease were isolated from a newly isolated bacterium (Bacillus subtilis strain Rand). The bacterium was identified, based on the $16 \mathrm{~S}$ rDNA analysis, biochemical tests and morphological study conducted.

It can be concluded that the maximum bacterial growth and production of protease were achieved under optimized conditions.

The extra-cellular protease was found to exhibit a remarkable stability towards several organic solvents. In more specific, it was found to retain $100 \%$ and $80 \%$ activity at 55 and $60^{\circ} \mathrm{C}$, respectively, after $30 \mathrm{~min}$ of incubation.

\section{Methods \\ Bacterial isolation}

The bacteria used in this study were isolated from contaminated soil mixed with engine oil collected from a car service workshop in Port Dickson, Malaysia. A soil sample (3 g) was suspended in a sterilized Tryptic Soy Broth (TSB) $(50 \mathrm{ml})$. The sample was incubation at $50^{\circ} \mathrm{C}$ (the temperature during sampling) with an agitation rate at $150 \mathrm{rpm}$ for $24 \mathrm{hr}$.

\section{Identification of the bacteria}

In this study, Bacillus subtilis strain Rand was identified based on the 16S rDNA analysis, morphological properties and biochemical characteristics. The 16S rDNA sequence was amplified via the polymerase chain reaction (PCR), using two universal primers, known as forward ( 5 'GAGTTTGATCCTGGCTCAG-3') and reverse (5'CGGCTACCTTGTTACGACTT-3'). The 16S rDNA sequence of Bacillus subtilis strain Rand was analyzed using the software package MEGA 4 [35]. Prior to gram staining, pure bacterial strain was streaked on the nutrient agar plate and incubated for $24 \mathrm{~h}$ at $50^{\circ} \mathrm{C}$ for the morphological study. An observation of this was then done under a light microscope. The morphological and physiological characteristics were further determined at Deutsche Sammlung Von Mikroorganismen (DSMZ), Germany. The physiological characteristics study included catalase and oxidase test, anaerobic growth, Voges-Proskauer test, growth at 30,50 and $55^{\circ} \mathrm{C}$, growth in medium at $\mathrm{pH} 5.7$, $2 \%, 5 \%, 7 \%$ and $10 \% \mathrm{NaCl}$, fermentation of D-glucose, Larabinose, D- xylose, D-mannitol, D-fructose, hydrolysis starch, gelatine, casein and Tween 80 , use of citrate and propionate, nitrate reduction, indole production, phenylalanine deaminase and arginine dihydrolase test.

\section{Production media and growth condition}

The culture was grown in standard $500 \mathrm{ml}$ blue cap bottle containing $50 \mathrm{ml}$ of production media. The medium consisted of $(\mathrm{g} / \mathrm{l}) ; \mathrm{CaCl}_{2} \cdot 2 \mathrm{H}_{2} \mathrm{O} \quad 0.5, \mathrm{KH}_{2} \mathrm{PO}_{4} \quad 0.2$, $\mathrm{MgSO}_{4} .7 \mathrm{H}_{2} \mathrm{O} 0.5, \mathrm{NaCl} 0.1$ and $1 \%$ peptone [36]. The $\mathrm{pH}$ of the media was adjusted to 7.0 before being autoclaved at $121^{\circ} \mathrm{C}$ for $15 \mathrm{~min}$. The bacterium was grown for $18 \mathrm{~h}$ at $37^{\circ} \mathrm{C}$ on a shaker at $150 \mathrm{rpm}$. The culture was centrifuged at $10,000 \times \mathrm{g}$ for $10 \mathrm{~min}$ and the supernatant was used as crude enzyme for further study.

\section{Protease assay}

The protease activity was determined by a slight modification method proposed by Rahman et al. [37]. Azocasein $(0.5 \%, 1 \mathrm{ml})$ was dissolved in $0.1 \mathrm{M}$ Tris-HCl- $2 \mathrm{mM} \mathrm{CaCl}_{2}$ pH7.0. The reaction was initiated by adding $100 \mu \mathrm{l}$ of enzyme solution into the azocasein solution and incubated at $50^{\circ} \mathrm{C}$ for $30 \mathrm{~min}$. An equal volume of $10 \%(\mathrm{w} / \mathrm{v})$ TCA was added to terminate the reaction, and the mixture was then allowed at room temperature for $30 \mathrm{~min}$, before 
centrifugation in eppendoft micro-centrifuge at 13,000 $\times$ $\mathrm{g}$ for $10 \mathrm{~min}$. The supernatant was removed and mixed with an equal volume of $1 \mathrm{~N} \mathrm{NaOH}$. The absorbance was read at $450 \mathrm{~nm}$. One unit of protease activity is defined in the assay conditions, giving an increase of 0.001 absorbance unit at $450 \mathrm{~nm}$ per minute [38]. As a control, the enzyme was added at the end of the incubation period.

\section{Protein assay}

Protein was measured using the method suggested by Bradford [39], with bovine serum albumin as the standard.

\section{Organic solvent-stability of crude enzyme}

Three millilitre of crude protease was incubated with 1.0 $\mathrm{ml}$ of organic solvent at $50^{\circ} \mathrm{C}$ with a constant shaking at $150 \mathrm{rpm}$ for $30 \mathrm{~min}$. The proteolytic activities were measured at zero time and the after incubation period using the assay method described above. For control, the solvent was replaced by distilled water. The organic solvents chosen in this study were toluene, $n$-tetradecane, $n$-hexadecane, $n$-dodacane, pyridine, $p$-xylene, $n$-hexane, benzene, $n$-decane and butanol.

\section{Thermostability of crude enzyme}

In this research, the effects of temperature on the crude protease stability were studied. The crude enzyme (without any $\mathrm{CaCl}_{2}$ ) was incubated for $30 \mathrm{~min}$ at different temperatures $\left(37,40,45,50,55,60,65,70^{\circ} \mathrm{C}\right)$. The treated enzyme was immediately put in ice-bath for $15 \mathrm{~min}$ before measuring the activity. The proteolytic activities were measured at zero time and after the incubation period, using the assay method described in the earlier section.

\section{The effect of temperature on the production of protease}

The ability of the Bacillus subtilis strain Rand to grow and produce protease, at elevated temperatures $\left(30\right.$ to $65^{\circ} \mathrm{C}$ ), was studied. For this purpose, separate cultures were incubated at $30,37,40,45,50,55,60$ and $65^{\circ} \mathrm{C}$ for $24 \mathrm{~h}$, with agitation at $150 \mathrm{rpm}$.

\section{The effect of $\mathrm{pH}$ on the production of protease}

A loop-full of $24 \mathrm{~h}$-old single colony of Rand strain was transferred from a fresh Nutrient agar plate into a $1 \mathrm{~L}$ blue cap bottle of production medium (pH 7.0). The culture was incubated at $37^{\circ} \mathrm{C}$ and $150 \mathrm{rpm}$ on the shaker for 48 hours. Then, some samples were taken at $4 \mathrm{~h}$ intervals so as to determine the protease activity and the $\mathrm{pH}$ level of the culture medium. The effects of the initial medium $\mathrm{pH}$ on the growth and production of protease were studied by adjusting the media (with $1 \mathrm{M} \mathrm{NaOH}$ or $\mathrm{HCl}$ ) to different $\mathrm{pH}$ levels ranging from 4 to 13 . The media were autoclave, cooled and inoculated with an overnight culture of isolate Rand, and incubated at $37^{\circ} \mathrm{C}$ (optimum temperature for protease production) for $24 \mathrm{~h}$ under $150 \mathrm{rpm}$ of agitation rate.

The effects of agitation rate on the production of protease The effects of agitation rate on the growth and production of protease were studied by cultivating the bacteria under different agitation rates ( 0 to $250 \mathrm{rpm}$ ). These cultures were incubated at $37^{\circ} \mathrm{C}$ for $24 \mathrm{~h}$.

The effects of inoculum size on the production of protease The effects of bacterial inoculum size $\left(\mathrm{A}_{600}=0.5\right)$ on the growth and production of protease were investigated using different inoculum sizes ranging from 1 to $11 \%(\mathrm{v} /$ v). The cultures were incubated at $37^{\circ} \mathrm{C}$ for $24 \mathrm{~h}$, under the agitation rate of $200 \mathrm{rpm}$ (i.e. the optimum agitation rate for the production of protease). Each experiment was carried out in triplicates and the results were taken in the means of three independent determinations.

\section{Statistical analysis}

For statistical analysis, a standard deviation for each experimental result was calculated using the Excel Spreadsheets available in the Microsoft Excel.

\section{Competing interests}

The authors declare that they have no competing interests.

\section{Authors' contributions}

All authors have read and approved the final version of the manuscript.

\section{Acknowledgements}

This project was supported by the Ministry of Science, Technology and Innovation (MOSTI), Malaysia 07-0I-04-SSO0I.

\section{References}

I. Malathu R, Chowdhury S, Mishra M, Das S, Moharana P, Mitra J, Mukhopadhyay UK, Thakur AR, Chaudhuri SR: Characterization and wash performance analysis of microbial extracellular enzymes from East Calcutta Wetland in India. Am J Appl Sci 2008, 5:1650-1661.

2. Adinarayana K, Ellaiah P, Prasad DS: Purification and partial characterization of thermostable serine alkaline protease from a newly isolated Bacillus subtilis PE-II. AAPS PharmSciTech 2003, 4(4):56.

3. Rao MB, Tanksale AM, Ghatge MS, Deshpande VV: Molecular and biotechnological aspects of microbial proteases. Microbiol Mol Biol Rev 1998, 62:597-635.

4. Thumar J, Singh SP: Two-step purification of a highly thermostable alkaline protease from salt-tolerant alkaliphilic Streptomyces clavuligerus strain Mit-I. J Chromatogr B 2007, 854:198-203.

5. Turner P, Mamo G, Karlsson EN: Potential and utilization of thermophiles and thermostable enzymes in biorefining. Microb Cell Fact 2007, 6: I-23.

6. Priest FG: Extracellular enzyme synthesis in the genus Bacillus. Bacteriol Rev 1977, 41:71 I-753.

7. Nascimento WCA, Martins MLL: Production and properties of an extracellular protease from thermophilic Bacillus sp. Braz J Microbiol 2004, 35:9I-96.

8. Haki GD, Rakshit SK: Developments in industrially important thermostable enzymes: a review. Bioresource Technol 2003, 89:17-34. 
9. Zamost BL, Nielsen HK, Starnes RL: Thermostable enzymes for industrial applications. J Ind Microbiol Biot 199|, 8:7I-82.

10. Sheldon RA: Large scale enzymatic conversions in non-aqueous media. In Enzymatic Reactions in Organic Media Edited by: Koskinen AMP, Klibanov AM. London: Chapman and Hall; 1996:266-302.

II. Gupta A, Khare SK: Enhanced production and characterization of a solvent stable protease from solvent tolerant Pseudomonas aeruginosa PseA. Enzyme Microb Tech 2007, 42:I I-16.

12. Ghorbel B, Kamoun AS, Nasri M: Stability studies of protease from Bacillus cereus BG I. Enzyme Microb Tech 2003, 32:5 I3-5I 8.

13. Kumar CG, Takagi H: Microbial alkaline proteases from a bioindustrial view point. Biotechnol Adv 1999, 17:56I-594.

14. Rahman RNZR, Geok LP, Basri M, Salleh AB: Physical factors affecting the production of organic solvent-tolerant protease by Pseudomonas aeruginosa strain K. Bioresource Technol 2005, 96:429-436.

15. Wang JJ, Shih JCH: Fermentation production of keratinase from Bacillus licheniformis PWD-I and a recombinant $B$. subtilis FDB-29. J Ind Microbiol Biot 1999, 22:608-616.

16. Thompson JD, Higgins DG, Gibson TJ: CLUSTAL W: improving the sensitivity of progressive multiple sequence alignment through sequence weighting, position-specific gap penalties and weight matrix choice. Nucleic Acids Res 1994, 22:4673-4680.

17. Wang SL, Yeh PY: Production of a surfactant- and solvent-stable alkaliphilic protease by bioconversion of shrimp shell wastes fermented by Bacillus subtilis TKU07. Process biochem 2006, 41 : I545-1552.

18. Ogino $\mathrm{H}$, Yasui $\mathrm{K}$, Shiotani $\mathrm{T}$, Ishihara $\mathrm{T}$, Ishikawa $\mathrm{H}$ : Organic solvent-tolerant bacterium which secretes an organic solventstable proteolytic enzyme. Appl Environ Microbiol 1995 , 6I:4258-4262.

19. Gupta A, Roy I, Khare SK, Gupta MN: Purification and characterization of a solvent stable protease from Pseudomonas aeruginosa PseA. J Chromatogr A 2005, 1069:|55-|6|.

20. Geok LP, Razak CNA, Rahman RNZA, Basri M, Salleh AB: Isolation and screening of an extracellular organic solvent-tolerant protease producer. Biochem Eng / 2003, 13:73-77.

21. Karadzic I, Masuib A, Fujiwara N: Purification and characterization of a protease from Pseudomonas aeruginosa grown in cutting oil. J Biosci Bioeng 2004, 98: 145-152.

22. Laane C, Boeren S, Vos K, Veeger C: Rules for the optimization of biocatalysis in organic solvents. Biotechnol Bioeng 1987, 30:8I-87.

23. Ogino $H$, Uchiho $T$, Doukyu $N$, Yasuda M, Ishimi $K$, Ishikawa $H$ : Effect of exchange of amino acid residues of the surface region of the PST-0I protease on its organic solvent-stability. Biochem Biophys Res Commun 2007, 358:1028-1033.

24. Wang SL, Kao TY, Wang CL, Yen YH, Chern MK, Chen YH: A solvent stable metalloprotease produced by Bacillus sp. TKU004 and its application in the deproteinization of squid pen for $\beta$-chitin preparation. Enzyme Microb Tech 2006 39:724-73I.

25. Chantawannakula $P$, Oncharoena $A$, Klanbuta $K$, Chukeatiroteb $E$ Lumyong S: Characterization of proteases of Bacillus subtilis strain $\mathbf{3 8}$ isolated from traditionally fermented soybean in Northern Thailand. Sci Asia 2002, 28:24I-245.

26. Gouda MK: Optimization and purification of alkaline proteases produced by marine Bacillus sp. MIG newly isolated from Eastern Harbour of Alexandria. Pol J Microbiol 2006 55:119-126.

27. Abdulrahman AM, Yasser MS: Production and some properties of protease produced by Bacillus licheniformis isolated from Aseer, Saudi Arabia. Pakistan J Biol Sci 2004, 7:1631-1635.

28. Frankena J, Koningstein GM, Verseveld HW, Stouthamer AH: Effect of different limitations in chemostat cultures on growth and production of exocellular protease by Bacillus licheniformis. Appl Microbiol Biotechnol 1986, 24:106-I I2.

29. Johnvesly B, Naik GR: Studies on production of thermostable alkaline protease from thermophilic and alkaliphilic Bacillus sp. JB-99 in a chemically defined medium. Process Biochem 2001, 37:139-144.

30. Moon SH, Parulekar SJ: Aparametric study of protease production in batch andfed-batch cultures of Bacillus firmus. Biotechnol Bioeng |99|, 37:467-483.
31. Roychoudhury S, Parulekar SJ, Weigand WA: Cell Growth and aAmylase Production Characteristics of Bacillus amyloliquefaciens. Biotechnol Bioeng 1988, 33:197-206.

32. Mabrouk SS, Hashem AM, El-Shayeb NMA, Ismail AMS, Abdel-Fattah AF: Optimization of alkaline protease productivity by Bacillus licheniformis ATCC2 1415. Bioresource Technol 1999, 69:155-159.

33. Shafee N, Aris SN, Rahman RNZA, Basri M, Salleh AB: Optimization of environmental and nutritional conditions for the production of alkaline protease by a newly isolated bacterium Bacillus cereus strain I46. J Appl Sci Res 2005, I:I-8.

34. Mehrotra S, Pandey PK, Gaur R, Dramwal NS: The production of alkaline protease from Aspergillus flavus culture filtrates. Appl Microbiol Biot 1999, 46: I38-| 42

35. Tamura K, Dudley J, Nei M, Kumar S: MEGA4: Molecular Evolutionary Genetics Analysis (MEGA) software version 4.0. Mol Biol Evol 2007, 24:1596-1599.

36. Rahman RNZR, Basri M, Salleh AB: Thermostable alkaline protease from Bacillus stearothermophilus FI; nutritional factors affecting protease production. Ann Microbiol 2003, 53:199-210.

37. Rahman RNZA, Razak CNAR, Ampon K, Basri M, Yunus WMZW, Salleh $A B$ : Purification and characterisation of heat-stable alkaline protease from Bacillus stearothermophilus FI. Appl Microbiol Biot 1994, 40:822-827.

38. Sarath G, De La Motte RS, Wagner FW: Protease assay methods. In Proteolytic Enzymes: a practical approach Edited by: Beynon RJ, Bond JS. Oxford: IRL Press; 1 989:25-55.

39. Bradford MM: A rapid and sensitive method for the quantitation of microgram quantities of protein utilizing the principle of protein-dye binding. Anal Biochem 1976, 72:248-54.
Publish with Biomed Central and every scientist can read your work free of charge

"BioMed Central will be the most significant development for disseminating the results of biomedical research in our lifetime. "

Sir Paul Nurse, Cancer Research UK

Your research papers will be:

- available free of charge to the entire biomedical community

- peer reviewed and published immediately upon acceptance

- cited in PubMed and archived on PubMed Central

- yours - you keep the copyright
BioMedcentral 